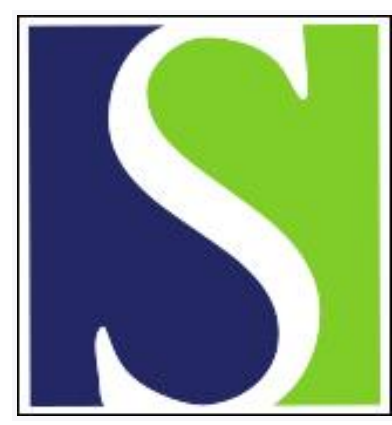

Scand J Work Environ Health 2000;26(6):492-500

https://doi.org/10.5271/sjweh.573

Issue date: Dec 2000

Semen quality and sexual hormones in greenhouse workers

by Abell A, Ernst E, Bonde JP

The following article refers to this text: 2007;33(1):13-28

Key terms: fertility; occupation; pesticide; re-entry; sperm; testis

This article in PubMed: www.ncbi.nlm.nih.gov/pubmed/11201396

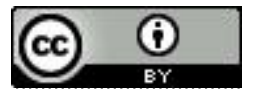




\title{
Semen quality and sexual hormones in greenhouse workers
}

\author{
by Annette Abell, PhD, ${ }^{1}$ Erik Ernst, $P h D,{ }^{2}$ Jens Peter Bonde, $P h D^{1}$
}

\begin{abstract}
Abell A, Ernst E, Bonde JP. Semen quality and sexual hormones in greenhouse workers. Scand J Work Environ Health 2000;26(6):492-500.
\end{abstract}

\begin{abstract}
Objectives This study focused on determining the testicular function of greenhouse workers exposed to pesticides. Meihods Semen was examined for 122 of 199 eligible men (61\%) from 30 ornamental flower greenhouses. Sperm concentration, morphology, and viability were measured according to World Health Organization guidelines, and the curvilinear sperm velocity was determined by a computer-assisted analysis of video recordings. Three groups were formed according to expert judgment of current exposure to pesticides from cultures, pesticide formulations, and the transfer of pesticide residues from leaves to hands, and also ranked according to years of work in a greenhouse. The risk estimates were adjusted for the effects of sexual abstinence and other potentially confounding factors.

Results According to current exposure the median values of sperm concentration and the proportion of normal spermatozoa were $60 \%$ and $14 \%$ lower, respectively, in the high-level exposure group $(\mathrm{N}=13)$ than in the low-level group ( $\mathrm{N}=44$ ), and the values of the intermediate group fell in between. The adjusted differences between the highlevel and low-level exposure groups were statistically significant, while no differences were observed for the viability and velocity of sperm and sexual hormones. The median sperm concentration was $40 \%$ lower for the men with $>10$ years' experience in a greenhouse than for those with $<5$ years' experience. The age-adjusted testosterone/ sex-hormone-binding globulin ratio declined $1.9 \%$ (95\% confidence interval $0.4-3.4 \%$ ) per year of work.

Conclusions The results are compatible with the hypothesis that male fecundity may be at risk from exposure to pesticides in the manual handling of cultures in greenhouses.
\end{abstract}

Key terms fertility, occupation, pesticide, re-entry, sperm, testis.

Reproductive effects as a result of occupational exposure to pesticides continue to be an issue of concern (1, 2). Animal testing indicates male reproductive toxicity in association with several pesticides currently in use in Danish greenhouses. The fungicides benomyl and carbendazim are microtubule disruptors $(3,4)$. Two metabolites of the fungicide vinclozolin have shown an affinity for the male androgen receptor and resulted in blockage of androgen activity. Iprodione, a dicarboximide fungicide as is vinclozolin, has less affinity for the androgen receptor, but exposure leads to decreased testosterone production $(5,6)$. The organochlorides lindane and endosulfan seem to impair steroid synthesis in the Leydig cells (7-9). Other pesticides, such as deltamethrin, fenvalerate, methomyl, dichlorvos, dimethoate, thiram, mancozeb, and captan, have exhibited effects on spermatogenesis in animals or mutagenic effects in such genotoxicity tests on rodent germ cells as the dominant lethal test, the specific locus test, and the heritable translocation test (10-19). Among these pesticides the lowest occupational exposure limit for reprotoxic effects in males is 4 milligrams per kilogram of body weight per day.

Work in greenhouses can involve primary exposure to pesticides during mixing and spraying or secondary exposure during the handling of sprayed cultures - also defined as re-entry exposure. Exposure is mostly through the skin on hands and forearms. The magnitude of exposure depends on the amount of dislodgeable foliar residue, job task, size of cultures, and type and formulation

1 Department of Occupational Medicine, Aarhus University Hospital, Denmark.

2 Institute of Anatomy, Aarhus University Hospital, Denmark.

Reprint requests to: Dr Annette Abell, Department of Occupational Medicine, Aarhus University Hospital, Noerrebrogade 44, DK 8000 Aarhus, Denmark. [E-mail annetteabell@dadlnet.dk] 
of pesticides. Through manual contact with cultures the transfer of pesticides to gloves, pads or hands varies from a few micrograms to a few milligrams per hour (2025). Few studies deal with the actual absorption of pesticides in relation to re-entry activities in greenhouses. Internal exposure ranges from $0 \mathrm{mg} /$ day to a little less than $1 \mathrm{mg} /$ day (24 26). In a study comparing internal exposure in relation to different work tasks the benomyl metabolite methyl-5-hydroxy-2-benzimidazole carbamate (5-HBC) was measured (27). Among these workers, the application of benomyl seemed to be associated with about double the uptake that occurs in re-entry activities. As external exposure has been measured as milligrams per hour, internal exposure at the lowest occupational exposure level may produce male reproductive toxicity. We hypothesized that the testicular function of ornamental greenhouse workers is at risk from dermal exposure to pesticide residues during re-entry activities. This paper reports the results of a cross-sectional semen study on this hypothesis.

\section{Subjects and methods}

\section{Recruitment}

In the autumn of 1993 we identified 38 greenhouses, each with a minimum of 3 male employees. The owners of 34 of these 38 greenhouses permitted a meeting for all male workers at the workplace. In 30 greenhouses at least 1 person consented to participate, in 2 greenhouses no one fulfilled the eligibility criteria (male, age 18 - 45 years, normal puberty, no vasectomy, no known azoospermia, no malignant disease, and no intake of sulfasalazine, beta-adrenergic blocking drugs or androgens), and in 2 greenhouses, one with 3 employees and one with 5 employees, all declined participation. Among 199 eligible men employed in the 34 greenhouses, 124 agreed to participate, and 122 provided a semen sample $(61 \%)$. The age distribution of the participants and nonparticipants is given in table 1 , the characteristics of the 122 workers who gave a semen sample and therefore formed the study group for this investigation are shown in table 2 , and table 3 presents the characteristics of the 30 greenhouses in which the 122 workers were employed.

\section{Data collection}

The greenhouse workers provided the semen sample in the winter of 1993-1994 (14 December to 11 March). Blood samples for the measurement of plasma levels of testosterone, follicle stimulating hormone (FSH) and luteinizing hormone (LH), and cholinesterase were taken concomitantly. All the semen and blood samples were collected between 0600 and 1000 . The semen ejaculates were obtained at home by masturbation directly into a 50-ml polyethylene jar and kept there until the analysis. The men were instructed to provide the sample within 1 hour after collection and to keep the sample in a pocket close to the body during transportation from the home to the workplace. At the workplace the samples were received by the project team, and the primary analysis and preparation was undertaken in a mobile laboratory (28). All the samples were examined by the same trained laboratory technician. A certain duration of sexual abstinence was not requested, but the accurate period of continence $(<12$ hours, $12-24$ hours or exact number of full days), febrile illness within the last 3 months (body temperature measured above $38.5^{\circ} \mathrm{C}$ ), and spillage during the collection were recorded.

A comprehensive questionnaire with self-completed information on reproductive, medical, occupational, and life-style history was checked by a physician. Job tasks were recorded at the start of the study and during 2 weeks in the autumn of 1994. The greenhouse owners, foremen, and applicators provided information on all pesticide applications from October 1993 to October 1994 (type of pesticide, size of area, number of hours, method of application, use of protective equipment).

\section{Laboratory analysis}

The semen volume was measured in a graded tube at an accuracy of $0.1 \mathrm{ml}$. The sperm concentration was counted after 1:1 dilution with a formalin buffer in a Makler chamber (volume $4.5 \mu \mathrm{l}$ ) using the phase-contrast technique at a magnification of 200 . The morphology was classified according to the 1992 criteria of the World Health Organization (29). Smears were air-dried, fixed in a mixture of ethanol and ether, and stained using a modification of Papanicolaou's stain. Eosin-Negrosin was used for vital staining. A 30 -second video recording of motility was made 3 times in different fields on undiluted and diluted semen (1:1 dilution with Mar-test buffer). A computer-assisted analysis was undertaken with the Hobson Sperm Tracker system. Of several possible measures of motility, we selected curvilinear velocity for analysis. The sexual hormones were analyzed at

Table 1. Age distribution of the participants and nonparticipants. Information was missing for 22 nonparticipants.

\begin{tabular}{lccrrr}
\hline \multirow{2}{*}{ Age (years) } & \multicolumn{2}{c}{ Participants } & & \multicolumn{2}{c}{ Nonparticipants } \\
\cline { 2 - 3 } \cline { 5 - 6 } & $N$ & & & N & $\%$ \\
\hline $18-19$ & 5 & 50 & & 5 & 50 \\
$20-24$ & 37 & 76 & & 2 & 24 \\
$25-29$ & 39 & 71 & & 16 & 29 \\
$30-34$ & 24 & 63 & & 14 & 37 \\
$35-39$ & 11 & 58 & 8 & 42 \\
\hline
\end{tabular}


Table 2. Characteristics of the 122 greenhouse workers according to their duration of work in ornamental greenhouses and their estimated

\begin{tabular}{|c|c|c|c|c|c|c|c|c|c|c|}
\hline \multirow[b]{3}{*}{ Subgroup of workers } & \multicolumn{10}{|c|}{ Person-related characteristics } \\
\hline & \multicolumn{2}{|c|}{ Age (years) } & \multirow{2}{*}{$\begin{array}{l}\text { Cryp- } \\
\text { torch- } \\
\text { Idism } \\
(\%)\end{array}$} & \multirow{2}{*}{$\begin{array}{l}\text { Tobac- } \\
\text { co- } \\
\text { smok- } \\
\text { ers } \\
(\%)\end{array}$} & \multicolumn{2}{|c|}{$\begin{array}{l}\text { Alcohol } \\
\text { consumption, } \\
\text { (drinks/week) }^{b}\end{array}$} & \multicolumn{2}{|c|}{$\begin{array}{l}\text { Caffeine } \\
\text { consumption, } \\
\text { (mg/week) }\end{array}$} & \multicolumn{2}{|c|}{$\begin{array}{l}\text { Body mass } \\
\text { inde } \\
\left(\mathrm{kg} / \mathrm{m}^{2}\right)\end{array}$} \\
\hline & Mean & SD & & & Mean & SD & Mean & SD & Mean & SD \\
\hline \multicolumn{11}{|c|}{$\begin{array}{l}\text { Duration of work in } \\
\text { ornamental greenhouses }\end{array}$} \\
\hline $\begin{array}{l}0-4 \text { years }(N=37) \\
5-9 \text { years }(N=40) \\
\geq 10 \text { years }(N=45)\end{array}$ & $\begin{array}{l}23.9 \\
26.7 \\
33.4\end{array}$ & $\begin{array}{l}4.8 \\
2.9 \\
4.5\end{array}$ & $\begin{array}{l}5 \\
8 \\
9\end{array}$ & $\begin{array}{l}49 \\
31 \\
33\end{array}$ & $\begin{array}{l}10.2 \\
11.0 \\
10.1\end{array}$ & $\begin{array}{c}9.8 \\
10.9 \\
10.2\end{array}$ & $\begin{array}{l}2700 \\
3213 \\
4120\end{array}$ & $\begin{array}{l}2017 \\
2529 \\
2705\end{array}$ & $\begin{array}{l}22.9 \\
23.2 \\
23.3\end{array}$ & $\begin{array}{l}2.7 \\
2.5 \\
3.0\end{array}$ \\
\hline \multicolumn{11}{|l|}{$\begin{array}{l}\text { Estimated dermal } \\
\text { pesticide exposure }\end{array}$} \\
\hline $\begin{array}{l}\text { Low }(N=44) \\
\text { Medium }(N=65) \\
\text { High }(N=13)\end{array}$ & $\begin{array}{l}29.8 \\
27.2 \\
28.6\end{array}$ & $\begin{array}{l}5.3 \\
5.9 \\
5.6\end{array}$ & $\begin{array}{r}11 \\
6 \\
0\end{array}$ & $\begin{array}{l}36 \\
36 \\
46\end{array}$ & $\begin{array}{l}12.1 \\
9.5 \\
9.6\end{array}$ & $\begin{array}{l}9.9 \\
9.3 \\
8.3\end{array}$ & $\begin{array}{l}3446 \\
3265 \\
3954\end{array}$ & $\begin{array}{l}2414 \\
2670 \\
2263\end{array}$ & $\begin{array}{l}23.6 \\
23.1 \\
21.9\end{array}$ & $\begin{array}{l}3.0 \\
2.8 \\
2.2\end{array}$ \\
\hline
\end{tabular}

a Ranking described under exposure assessment.

b $33 \mathrm{cl}$ beer or $2 \mathrm{cl}$ of $45 \%$ alcoholic beverage.

c Cup of coffee $=100 \mathrm{mg}$, cup of tea $=50 \mathrm{mg}$, cup of hot chocolate $=25 \mathrm{mg}$, bottle of cola $=40 \mathrm{mg}$, piece of chocolate $=25 \mathrm{mg}(39)$.

Table 3. Greenhouse characteristics.

\begin{tabular}{lr}
\hline & Number of greenhouses \\
\cline { 2 - 2 } Area $\left(\mathrm{m}^{2}\right)$ & \\
$5000-9999$ & 10 \\
$10000-19999$ & 11 \\
$20000-50500$ & 9 \\
Production & \\
Monocultures & \\
$\quad$ Rosa hybrid (pot roses) & 3 \\
$\quad$ Kalanchöe blossfeldiana & 2 \\
$\quad$ Soleirolia solerolii & 1 \\
Begonia elatior hybrid & 3 \\
Gardenia & 1 \\
More than 1 culture & 20 \\
Number of workers aged 18-45 years & \\
$1-3$ & 9 \\
$4-9$ & 17 \\
$10-19$ & 4 \\
Participation rate & \\
$\leq 49 \%$ & 4 \\
$50-74 \%$ & 3 \\
$75-99 \%$ & 7 \\
$100 \%$ & \\
\hline
\end{tabular}

${ }^{a}$ More than 50 different cultures.

MediLab, in Copenhagen, Denmark. Serum concentrations of FSH and LH were measured with a microparticular enzyme immunoassay technique, plasma testosterone by radio immunoassay (RIA), and serum sex-hormone-binding globulin (SHBG) by an enzyme-linked immunosorbent assay (ELISA). The plasma cholinesterase activity was analyzed at Randers Regional Hospital, Randers, Denmark. The frozen plasma was thawed for 5 minutes at $37^{\circ} \mathrm{C}$ and diluted 1:5 with sodium chloride $(8.5 \mathrm{~g} / \mathrm{l})$ immediately preceding the analysis. Two dilu- tions were made and analyzed independently of each other. The results were recorded as the means of the 2 analyses. The analyses were done on a Cobas Fara centrifugal analyzer.

\section{Exposure assessment}

More than 60 pesticides were used in the 30 greenhouses. The insecticides included several compounds which exhibit male reproductive toxicity in some animals (MRT). The insecticides most often encountered were pirimicarp (in 26 greenhouses), methomyl (in 14 greenhouses, MRT found), deltamethrin (in 14 greenhouses, MRT found), endosulfan (in 12 greenhouses, MRT found), chlorpyrifos (in 9 greenhouses), buprofezin (in 9 greenhouses), dienochlor (in 8 greenhouses), fenpropathrin (in 7 greenhouses), alfacypermethrin (in 6 greenhouses), amitraz (in 4 greenhouses). The most used fungicides were benomyl (in 16 greenhouses, MRT found), iprodione (in 16 greenhouses, MRT found), chlortohalonil (in 13 greenhouses), carbendazim (in 8 greenhouses, MRT found), vinclozolin (in 8 greenhouses, MRT found), and thiram (in 4 greenhouses, MRT found). And, finally, the most common growth regulators were chlormequat chloride (in 23 greenhouses), daminozide (in 17 greenhouses), and praclobutrazol (in 12 greenhouses).

We defined 3 independent indicators of current exposure to pesticides during work in ornamental greenhouses. First, workers were classified according to the ratio between the area treated with pesticides during the 3 months prior to the collection of the semen sample relative to the total greenhouse area. A period of 3 months 
dermal pesticide exposure.

\begin{tabular}{|c|c|c|c|c|c|c|c|c|c|c|c|c|c|c|}
\hline & & & & & & & Semen-i & elated & aracteris & & & & & \\
\hline $\begin{array}{l}\text { Plasma } \\
\text { in } 1994\end{array}$ & $\begin{array}{l}\text { choline } \\
(\mathrm{kU} / \mathrm{l})\end{array}$ & terase & $\begin{array}{l}\text { Manua } \\
\text { handlit } \\
\text { culture } \\
\text { (hours }\end{array}$ & $\begin{array}{l}\text { g of } \\
\text { s day) }\end{array}$ & $\begin{array}{l}\text { Applic } \\
\text { of pest } \\
\text { (hours }\end{array}$ & $\begin{array}{l}\text { tion } \\
\text { cides } \\
\text { week) }\end{array}$ & $\begin{array}{l}\text { Duration } \\
\text { (days) }\end{array}$ & of abst & ance & $\begin{array}{l}\text { Fever } \\
\text { during } \\
\text { previous } \\
3 \text { months }\end{array}$ & $\begin{array}{l}\text { Spillage } \\
\text { at } \\
\text { sampling } \\
(\%)\end{array}$ & $\begin{array}{l}\text { Time fro } \\
\text { to analy }\end{array}$ & $\begin{array}{l}\text { samplin } \\
\text { (minute }\end{array}$ & \\
\hline Median & $\begin{array}{l}25 \text { th } \\
\text { per- } \\
\text { cent- } \\
\text { ile }\end{array}$ & $\begin{array}{l}\text { 75th } \\
\text { per- } \\
\text { cent- } \\
\text { ile }\end{array}$ & Mean & SD & Mean & SD & Median & $\begin{array}{l}25 \text { th } \\
\text { per- } \\
\text { cent- } \\
\text { ile }\end{array}$ & $\begin{array}{l}\text { 75th } \\
\text { per- } \\
\text { cent- } \\
\text { ile }\end{array}$ & & & Median & $\begin{array}{l}25 \text { th } \\
\text { per- } \\
\text { cent- } \\
\text { ile }\end{array}$ & $\begin{array}{l}75 \text { th } \\
\text { per- } \\
\text { cent- } \\
\text { ile }\end{array}$ \\
\hline $\begin{array}{l}8.5 \\
8.7 \\
8.1\end{array}$ & $\begin{array}{l}7.7 \\
7.4 \\
6.9\end{array}$ & $\begin{array}{l}9.7 \\
9.7 \\
10\end{array}$ & $\begin{array}{l}4.5 \\
5.2 \\
4.6\end{array}$ & $\begin{array}{l}2.6 \\
2.2 \\
2.3\end{array}$ & $\begin{array}{l}1.2 \\
1.9 \\
1.7\end{array}$ & $\begin{array}{l}1.3 \\
2.6 \\
2.4\end{array}$ & $\begin{array}{l}2 \\
2 \\
2\end{array}$ & $\begin{array}{l}0.8 \\
0.9 \\
0.9\end{array}$ & $\begin{array}{l}3 \\
4.5 \\
5\end{array}$ & $\begin{array}{l}19 \\
20 \\
27\end{array}$ & $\begin{array}{l}19 \\
23 \\
20\end{array}$ & $\begin{array}{l}45 \\
50 \\
48\end{array}$ & $\begin{array}{l}30 \\
40 \\
40\end{array}$ & $\begin{array}{l}55 \\
65 \\
65\end{array}$ \\
\hline $\begin{array}{l}8.7 \\
8.7 \\
7.5\end{array}$ & $\begin{array}{l}7.1 \\
7.6 \\
6.5\end{array}$ & $\begin{array}{l}10.3 \\
9.6 \\
9.7\end{array}$ & $\begin{array}{l}3.5 \\
5.6 \\
6.1\end{array}$ & $\begin{array}{l}2.4 \\
2.1 \\
1.8\end{array}$ & $\begin{array}{l}1.4 \\
1.4 \\
1.4\end{array}$ & $\begin{array}{l}0.5 \\
0.5 \\
2.5\end{array}$ & $\begin{array}{l}2 \\
2 \\
3\end{array}$ & $\begin{array}{l}0.8 \\
0.8 \\
2\end{array}$ & $\begin{array}{l}3 \\
4 \\
5\end{array}$ & $\begin{array}{l}20 \\
17 \\
54\end{array}$ & $\begin{array}{l}14 \\
25 \\
23\end{array}$ & $\begin{array}{l}40 \\
50 \\
53\end{array}$ & $\begin{array}{l}30 \\
40 \\
30\end{array}$ & $\begin{array}{l}52 \\
60 \\
70\end{array}$ \\
\hline
\end{tabular}

Table 4. Job tasks of the workers ranked according to estimated dermal exposure to pesticides.

\begin{tabular}{lll}
\hline Ranking & $\mathrm{N}$ & Job tasks \\
\hline Low level & 44 & $\begin{array}{l}\text { Administration, care and surveillance, } \\
\text { working with pot machine, moving tables, } \\
\text { newly hired } \\
\text { Packing, care and surveillance, spacing } \\
\text { Medium level } \\
\text { cultures, pricking and potting } \\
\text { Niping and cutting cuttings }\end{array}$ \\
\hline
\end{tabular}

Table 5. Sperm density according to intensity of pesticide application (ratio of area treated with pesticide/total greenhouse area) and work practice, respectively.

\begin{tabular}{lll}
\hline \multicolumn{3}{l}{ Sperm concentration (million/ml) } \\
\cline { 2 - 3 }$\quad$ Median $\begin{array}{l}25 \mathrm{th} \quad \begin{array}{l}75 \mathrm{th} \\
\text { percentile }\end{array} \\
\text { percentile }\end{array}$ \\
\hline
\end{tabular}

Related to greenhouse

Ratio for all pesticides

$$
\begin{aligned}
& <3 \\
& 3-6 \\
& 6-9 \\
& >9
\end{aligned}
$$

Ratio for insecticides

$$
\begin{aligned}
& <1 \\
& 1-2 \\
& 2-3 \\
& >3
\end{aligned}
$$

Ratio for fungicides

$$
\begin{aligned}
& <0.5 \\
& 0.5-1 \\
& 1-1.5 \\
& >1.5
\end{aligned}
$$

$\begin{array}{rrr}29 & 88 & 46 \\ 45 & 66 & 3 \\ 29 & 102 & 38 \\ 17 & 60 & 34 \\ & & \\ 48 & 87 & 32 \\ 25 & 138 & 62 \\ 45 & 66 & 34 \\ 4 & 121 & 7\end{array}$

$\begin{array}{ll}46 & 11 \\ 36 & 14 \\ 38 & 248 \\ 34 & 102 \\ & \\ 32 & 134 \\ 62 & 258 \\ 34 & 106 \\ 77 & 127\end{array}$

$\begin{array}{rrr}55 & 70 & 32 \\ 19 & 62 & 42 \\ 20 & 102 & 57 \\ 28 & 97 & 30\end{array}$

(continued)
Table 5. Continued.

\begin{tabular}{lll}
\multicolumn{3}{c}{ Sperm concentration (million/ml) } \\
\hline$N \quad$ Median & $\begin{array}{l}25 \mathrm{th} \\
\text { percentile }\end{array}$ & 75th \\
& percentile
\end{tabular}

Ratio for growth regulators

$$
\begin{aligned}
& 0 \\
& 0-2 \\
& 2-4 \\
& >4
\end{aligned}
$$

$\begin{array}{llll}31 & 68 & 38 & 128 \\ 32 & 88 & 54 & 119 \\ 34 & 95 & 32 & 200 \\ 25 & 90 & 34 & 150\end{array}$

Ratio for possible spermatotoxic

$$
\begin{aligned}
& <1 \\
& 1-2 \\
& 2-4 \\
& >4
\end{aligned}
$$

$\begin{array}{rrrr}66 & 88 & 32 & 134 \\ 22 & 66 & 38 & 116 \\ 16 & 180 & 44 & 289 \\ 18 & 65 & 34 & 106\end{array}$

Related to worker

Daily number of hand washes

$\begin{array}{lllll}<3 & 10 & 34 & 16 & 159 \\ 4-6 & 78 & 95 & 46 & 160 \\ >6 & 33 & 66 & 24 & 112\end{array}$

Daily hours in contact

with cultures

\begin{tabular}{lrrrr}
$<2$ & 18 & 80 & 42 & 112 \\
$2-4$ & 18 & 60 & 28 & 100 \\
$>4$ & 86 & 95 & 36 & 160 \\
Use of gloves & & & & \\
$\quad$ Always & 20 & 71 & 62 & 118 \\
$\quad$ Sometimes & 48 & 64 & 30 & 134 \\
$\quad$ Never & 53 & 100 & 36 & 160 \\
Application & & & & \\
$\quad$ Yes & 75 & 88 & 42 & 160 \\
$\quad$ No & 47 & 70 & 28 & 138 \\
Weekly hours with application & & & & \\
$<1$ & 40 & 83 & 51 & 145 \\
$1-2$ & 18 & 67 & 26 & 182 \\
$>2$ & 17 & 88 & 62 & 106 \\
\hline
\end{tabular}

Scand J Work Environ Health 2000, vol 26, no 6 
was chosen to allow for effects on the early stages of the spermatogenesis, lasting 72 days in humans. The ratio was computed for each type of pesticide (fungicides, insecticides, growth regulators, and possible spermatotoxic agents). A ratio above 1 indicated that some or all areas had been treated more than once during the period. For all the pesticides the ratio was 4.6 , and for possible male reproductive toxicants it was 1.0. Second, workers were classified according to job task and work practice. The exposure categories were the time in contact with pesticide-treated cultures $(0-2,3-4,5-8$ hours per day), the number of hand washes a day $(0-2,3-5$, at least 6), use of gloves (always, sometimes, never), application of pesticides [yes, no; if yes: hours per week $(<1,1-<2, \geq 2)$, and use of protective equipment (yes, no)]. Third, the workers were ranked into 3 groups according to an evaluation of the transfer of pesticide resi- dues from cultures to hands. Each worker was assigned the worktask performed most of the time during a 2-week period in the autumn of 1994, when diaries on worktasks were kept. For 29 workers the classification was based on the most common task in the winter of 1993-1994. Registration of the job tasks over a period of 14 days is believed to provide a reliable estimate of tasks and work practices during the past year. All worktasks were assigned a rank to indicate the relative dermal transfer factor, and finally the worktask ranks were modified by the size of the cultures and the amount of pesticide used in a particular greenhouse. The evaluation was supported by measurements of pesticide residues on gloves and dislodgeable foliar residues during 8 tasks in 3 greenhouses (30), but the measurements for other tasks and in other greenhouses were estimated. The classification was undertaken by 2 agronomists and an occupational health

Table 6. Sperm characteristics in relation to the ranking of current dermal pesticide exposure. $(95 \% \mathrm{Cl}=95 \%$ confidence interval, $O \mathrm{R}=$ odds

\begin{tabular}{|c|c|c|c|c|c|c|c|c|c|c|c|c|c|c|c|}
\hline \multirow[b]{3}{*}{$\begin{array}{l}\text { Ranking of } \\
\text { pesticide } \\
\text { exposure }\end{array}$} & \multicolumn{5}{|c|}{ Concentration $(\mathrm{mm} / \mathrm{ml})$} & \multicolumn{5}{|c|}{ Velocity $(\mu \mathrm{m} / \mathrm{s})$} & \multicolumn{5}{|c|}{ Proportion of normal sperm } \\
\hline & \multicolumn{3}{|c|}{ Unadjusted } & \multicolumn{2}{|c|}{ Adjusted } & \multicolumn{3}{|c|}{ Unadjusted } & \multicolumn{2}{|c|}{ Adjusted } & \multirow[t]{2}{*}{ Median } & \multirow{2}{*}{$\begin{array}{l}25 \text { th } \\
\text { per- } \\
\text { centile }\end{array}$} & \multirow{2}{*}{$\begin{array}{l}\text { 75th } \\
\text { per- } \\
\text { centile }\end{array}$} & \multicolumn{2}{|c|}{ Unadjusted } \\
\hline & $\begin{array}{l}\text { Me- } \\
\text { dian }\end{array}$ & $\begin{array}{l}25 \text { th } \\
\text { per- } \\
\text { centile }\end{array}$ & $\begin{array}{l}75 \text { th } \\
\text { per- } \\
\text { centile }\end{array}$ & Mean ${ }^{a}$ & a $95 \% \mathrm{Cl}$ & $\begin{array}{l}\text { Me- } \\
\text { dian }\end{array}$ & $\begin{array}{l}\text { 25th } \\
\text { per- } \\
\text { centile }\end{array}$ & $\begin{array}{l}75 \text { th } \\
\text { per- } \\
\text { centile }\end{array}$ & Mean a & $95 \% \mathrm{Cl}$ & & & & OR & $95 \% \mathrm{Cl}$ \\
\hline $\begin{array}{l}\text { Low level } \\
(\mathrm{N}=44)\end{array}$ & 87 & 38 & 172 & 93 & & 62 & 52 & 74 & 63 & . & 71 & 63 & 73 & 1.00 & . \\
\hline $\begin{array}{l}\text { Medium level } \\
(\mathrm{N}=65)\end{array}$ & 88 & 42 & 146 & 85 & $58-117$ & 65 & 58 & 73 & 65 & $54-76$ & 65 & 57 & 74 & 0.87 & $0.71-1.05$ \\
\hline $\begin{array}{l}\text { Highlevel } \\
(\mathrm{N}=13)\end{array}$ & 36 & 26 & 80 & 47 & $22-88$ & 51 & 47 & 63 & 56 & $50-63$ & 61 & 46 & 71 & 0.68 & $0.48-0.95$ \\
\hline Test for trend & & & & 0.1 & & & & & 0.3 & & & & & & \\
\hline
\end{tabular}

adjusted mean calculated with the confounder distribution as among reference group. Confounders included age and urogenital disease, fever, spillage,

Table 7. Sperm characteristics and sex hormones in relation to years of work in ornamental greenhouses. (SHBG serum sex-hormone-

\begin{tabular}{|c|c|c|c|c|c|c|c|c|c|c|c|c|c|c|c|}
\hline \multirow{6}{*}{$\begin{array}{l}0-4 \text { years } \\
(\mathrm{N}=37) \\
5-9 \text { years } \\
(\mathrm{N}=40) \\
10-\text { years } \\
(\mathrm{N}=45)\end{array}$} & \multicolumn{5}{|c|}{ Concentration $(\mathrm{mm} / \mathrm{ml})$} & \multicolumn{5}{|c|}{ Velocity $(\mu \mathrm{m} / \mathrm{s})$} & \multicolumn{5}{|c|}{ Proportion of normal spermatozoa } \\
\hline & \multicolumn{3}{|c|}{ Unadjusted } & \multicolumn{2}{|c|}{ Adjusted } & \multicolumn{3}{|c|}{ Unadjusted } & \multicolumn{2}{|c|}{ Adjusted } & \multirow{2}{*}{$\begin{array}{l}\text { Me- } \\
\text { dian }\end{array}$} & \multirow{2}{*}{$\begin{array}{l}\text { 25th } \\
\text { per- } \\
\text { centile }\end{array}$} & \multirow{2}{*}{$\begin{array}{l}75 \text { th } \\
\text { per- } \\
\text { e centile }\end{array}$} & \multicolumn{2}{|c|}{ Unadjusted } \\
\hline & $\begin{array}{l}\text { Me- } \\
\text { dian }\end{array}$ & $\begin{array}{l}25 \text { th } \\
\text { per- } \\
\text { centile }\end{array}$ & $\begin{array}{l}75 \text { th } \\
\text { per- } \\
\text { centile }\end{array}$ & Mean a & $95 \% \mathrm{Cl}$ & $\begin{array}{l}\text { Me- } \\
\text { dian }\end{array}$ & $\begin{array}{l}\text { 25th } \\
\text { per- } \\
\text { centile }\end{array}$ & $\begin{array}{l}\text { 75th } \\
\text { per- } \\
\text { centile }\end{array}$ & Mean a & $95 \% \mathrm{Cl}$ & & & & $O R$ & $95 \% \mathrm{Cl}$ \\
\hline & 101 & 42 & 176 & 92 & & 67 & 59 & 82 & 69 & & 64 & 56 & 70 & 1.00 & \\
\hline & 71 & 52 & 126 & 75 & $47-101$ & 63 & 54 & 76 & 64 & $57-72$ & 67 & 31 & 75 & 1.18 & $0.94-1.49$ \\
\hline & 62 & 26 & 140 & 56 & $29-96$ & 64 & 53 & 75 & 61 & $52-70$ & 71 & 56 & 75 & 1.26 & $0.98-1.62$ \\
\hline Test for trend & & & & 0.08 & & & & & 0.06 & & & & & & \\
\hline
\end{tabular}

${ }^{a}$ Adjusted mean calculated with covariate distribution as among reference group. Confounders included age, urogenital disease, fever, spillage, time of

${ }^{\mathrm{b}}$ Adjusted for age, calculated with mean age of the reference group. 
physician, and the process was blinded as to the results of the semen analyses. Table 4 on page 495 shows the job tasks ranked at the 3 levels. The highest ranked group had the lowest level of plasma cholinesterase, but the difference was not statistically significant. Finally, the number of years worked in ornamental greenhouses was considered an indicator of the total exposure to pesticide during a lifetime.

\section{Data analysis and statistical methods}

We compared the seminal and sexual hormone values across the subgroups of greenhouse workers using multiple linear regression (31). In all the analyses the reference was the subgroup ranked lowest according to the exposure classification. The response variables included sperm concentration, proportion of nonvital sperm cells, proportion of sperm cells with normal morphology, curvilinear velocity, and sexual hormones (FSH, LH, testosterone). The concentration of total testosterone was adjusted by the concentration of SHBG to obtain a measure of unbound biological active testosterone. For normality of residuals and equality of variances, the sperm concentration was transformed to third roots, the proportions of nonvital spermatozoa and the proportion of morphologic normal spermatozoa were transformed by the logit function, and the testosterone: SHBG ratio and duration of abstinence were transformed by the logarithmic function. A fixed row of covariates was included in the model, namely, period of sexual abstinence (days), spillage at sample collection (yes, no), fever during the previous 3 months (yes, no), cryptorchidism or 1 testis in scrotum (yes, no), and time from ejaculation to analysis (in the analyses of motility and viability: $<0.5$ hour,

ratio, SHBG serum-sex-hormone binding globulin, $L H$ = luteinizing hormone)

\begin{tabular}{|c|c|c|c|c|c|c|c|c|c|c|c|c|c|c|c|c|}
\hline & & \multicolumn{7}{|c|}{ Proportion of nonvital spermatozoa } & \multicolumn{2}{|c|}{$\begin{array}{l}\text { Testosterone } \\
(\mathrm{nmol} / \mathrm{l})\end{array}$} & \multicolumn{2}{|c|}{$\begin{array}{l}\text { SHBG } \\
(\mathrm{nmol} / 1)\end{array}$} & \multicolumn{2}{|l|}{$\begin{array}{l}\mathrm{LH} \\
(\mathrm{IU} / \mathrm{I})\end{array}$} & \multicolumn{2}{|c|}{$\begin{array}{l}\text { SHBG } \\
(\mathrm{nmol} / \mathrm{l})\end{array}$} \\
\hline \multicolumn{2}{|c|}{ Adjusted } & \multirow[t]{2}{*}{ Median } & \multirow{2}{*}{$\begin{array}{l}25 \text { th } \\
\text { per- } \\
\text { centile }\end{array}$} & \multirow{2}{*}{$\begin{array}{l}\text { 75th } \\
\text { per- } \\
\text { centile }\end{array}$} & \multicolumn{2}{|c|}{ Unadjusted } & \multicolumn{2}{|c|}{ Adjusted } & \multirow[t]{2}{*}{ Mean } & \multirow[t]{2}{*}{ SD } & \multirow[t]{2}{*}{ Mean } & \multirow[t]{2}{*}{$\mathrm{SD}$} & \multirow{2}{*}{\multicolumn{2}{|c|}{ Mean SD }} & \multirow[t]{2}{*}{ Mean } & \multirow[t]{2}{*}{ SD } \\
\hline $\mathrm{OR}$ & $95 \% \mathrm{Cl}$ & & & & $\mathrm{OR}$ & $95 \% \mathrm{Cl}$ & $\mathrm{OR}$ & $95 \% \mathrm{Cl}$ & & & & & & & & \\
\hline 1.00 & & 23 & 14 & 31 & 1.00 & & 1.00 & . & 25.5 & 8.1 & 22.3 & 8.1 & 4.1 & 1.5 & 4.9 & 2.6 \\
\hline 0.84 & $0.67-1.03$ & 26 & 18 & 38 & 1.20 & $0.91-1.58$ & 1.03 & $0.76-1.39$ & 25.1 & 7.5 & 22.4 & 7.8 & 4.3 & 1.8 & 4.5 & 1.8 \\
\hline 0.67 & $0.47-0.95$ & 28 & 22 & 34 & 1.35 & $0.86-2.1$ & 1.20 & $0.76-1.88$ & 25.7 & 7.0 & 22.5 & 6.6 & 4.5 & 1.6 & 5.5 & 3.0 \\
\hline 0.02 & & & & & & & 0.49 & & 0.88 & & 0.85 & & 0.45 & & 0.77 & \\
\hline
\end{tabular}

time of abstinence, and, in calculations of velocity and viability, also time interval from masturbation to analysis.

binding globulin, $\mathrm{FSH}=$ follicle stimulating hormone)

\begin{tabular}{|c|c|c|c|c|c|c|c|c|c|c|c|c|c|c|c|c|c|c|}
\hline & & \multicolumn{7}{|c|}{ Proportion of nonvital spermatozoa } & \multicolumn{2}{|c|}{$\begin{array}{l}\text { Testosterone } \\
(\mathrm{nmol} / \mathrm{l})\end{array}$} & \multicolumn{2}{|c|}{$\begin{array}{l}\text { SHBG } \\
(\mathrm{nmol} / \mathrm{l})\end{array}$} & \multicolumn{2}{|l|}{$\begin{array}{l}\mathrm{LH} \\
(\mathrm{IU} / \mathrm{I})\end{array}$} & \multicolumn{2}{|l|}{$\begin{array}{l}\text { FSH } \\
(\mathrm{IU} / \mathrm{I})\end{array}$} & \multicolumn{2}{|c|}{$\begin{array}{l}\text { Testosterone/ } \\
\text { SHBG }\end{array}$} \\
\hline \multicolumn{2}{|c|}{ Adjusted } & \multirow{2}{*}{$\begin{array}{l}\text { Me- } \\
\text { dian }\end{array}$} & \multirow{2}{*}{$\begin{array}{l}\text { 25th } \\
\text { per- } \\
\text { centile }\end{array}$} & \multirow{2}{*}{$\begin{array}{l}\text { 75th } \\
\text { per- } \\
\text { centile }\end{array}$} & \multicolumn{2}{|c|}{ Unadjusted } & \multicolumn{2}{|c|}{ Adjusted } & \multirow[t]{2}{*}{ Mean } & \multirow[t]{2}{*}{ SD } & \multirow[t]{2}{*}{ Mean } & \multirow[t]{2}{*}{ SD } & \multicolumn{2}{|c|}{ Mean SD } & \multirow[t]{2}{*}{ Mean } & \multirow[t]{2}{*}{ SD } & \multicolumn{2}{|c|}{$\begin{array}{l}\text { Adjusted } 95 \% \mathrm{Cl} \\
\text { mean }\end{array}$} \\
\hline OR & $95 \% \mathrm{Cl}$ & & & & OR & $95 \% \mathrm{Cl}$ & OR & $95 \% \mathrm{Cl}$ & & & & & & & & & & \\
\hline 1.00 & & 24 & 15 & 32 & 1.00 & & 1.00 & . & 26.3 & 8.8 & 21.0 & 7.7 & 4.3 & 2.0 & 4.2 & 1.5 & 1.31 & \\
\hline 1.08 & $0.85-1.37$ & 25 & 21 & 33 & 1.32 & $0.95-1.84$ & 1.30 & $0.94-1.80$ & 26.2 & 7.8 & 22.6 & 8.0 & 4.1 & 1.4 & 4.7 & 2.2 & 1.21 & $1.05-1.41$ \\
\hline 1.38 & $0.99-1.90$ & 28 & 19 & 28 & 1.36 & $1.0-1.96$ & 1.68 & $1.1-2.6$ & 24.0 & 6.1 & 23.5 & 7.8 & 4.1 & 1.6 & 5.2 & 2.6 & 1.06 & $0.71-1.28$ \\
\hline 0.05 & & & & & & & 0.01 & & 0.16 & & 0.15 & & 0.84 & & 0.02 & & 0.008 & \\
\hline
\end{tabular}

abstinence, and, in calculations of velocity, also interval from masturbation to analysis. 
$0.5-<1$ hour, $\geq 1$ hour). Age was included in the analyses of the testosterone:SHBG ratio, FSH, and LH. Tobacco smoking caused less than a $10 \%$ change in the regression coefficients of the response variables of interest. As smoking may increase oral exposure to pesticides, this factor was not included in the models. The fit of the regression models was evaluated by testing the residuals for normality and by inspecting the residual plots. The adjusted group means of the concentration were calculated as the third power of the estimated means of the transformed variables and the group means of curvilinear velocity directly from the estimated coefficients. The adjusted means were calculated using the reference group distribution of the covariates. Since the proportions of normal sperm cells and nonvital sperm cells were logittransformed prior to the analyses, the coefficients in the multiple regression measured the effects on a logit scale. To facilitate interpretation, these effects were expressed as odds ratios (the ratio of the odds for a normal cell for an exposed person to the odds for a normal cell for a person in the reference group). The odds ratio was obtained as the exponential of the corresponding regression coefficient.

\section{Results}

The intensity of pesticide use in the greenhouses was not related to sperm concentration (table 5 on page 495) or any other semen characteristic. Nor did we find decreased semen quality among the workers who reported the highest number of hours in daily contact with pesticide-treated cultures or among applicators (table 5 on page 495). When the current exposure was estimated according to the transfer of pesticides from leaves to hands, the high-level group $(\mathrm{N}=13)$ had a $60 \%$ lower median sperm concentration and a $14 \%$ lower median proportion of normal spermatozoa than the low-level group $(\mathrm{N}=44)$ (table 6 on pages $496-497)$. The adjusted differences reached statistical significance (table 6 on pages 496-497), as did the test for trend with respect to the proportion of normal spermatozoa ( $\mathrm{P}=0.02)$.

The sperm concentration of the men with $1-2$ daily handwashes was low ( $\mathrm{N}=10$, median 34 million/ml), but the adjusted mean value of 55 million $/ \mathrm{ml}$ (95\% CI 23 108) was not significantly different from that of the group with at least 6 daily handwashes (mean 75 million/ml).

Sperm concentration, viability, and motility were inversely related to the total duration of work in ornamental greenhouses (table 7 on pages 496-497), while sperm morphology, if anything, improved with long-term exposure. The age-adjusted testosterone:SHBG ratio declined by $1.9 \%(95 \% \mathrm{Cl} 0.04 \%-3.4 \%)$ per year of work in a greenhouse. The sperm concentration and FSH were inversely related (Pearson correlation coefficient -0.34 , $\mathrm{P}<0.0001$ ), but FSH (and LH) did not show any consistent relation with length of employment.

\section{Discussion}

The number of years at work for ornamental greenhouses and the ranking of workers according to the judged level of current dermal pesticide exposure were related to sperm concentration, velocity, vitality, and morphology, even after adjustment for confounders. A higher number of years at work and a high ranking of current dermal exposure were associated with a deterioration in these measures of semen quality. However, the findings are only suggestive of a relation between exposure to pesticides during the manual handling of cultures and the impairment of testicular function, because the analysis relies on a crude evaluation of skin contact with pesticides while the actual exposure of the relevant tissues has not been documented. The plasma cholinesterase measurements did not indicate a clear increase across the subgroups of exposure to cholinesterase inhibitors although exposure to such compounds was highest in the high-level exposure group. Several other limitations of the study are discussed in the following.

The median sperm concentration of $86 \mathrm{million} / \mathrm{ml}$ for greenhouse workers was rather high in comparison with that of the other occupational groups studied in Denmark during recent years (32-34). Occupational sperm studies with low participation rates may not truly represent the source population (35), and earlier studies have found a preferential participation of men with reduced semen quality. In our study men with cryptorchidism volunteered 4.2 (95\% CI 0.6-29.8) times more often than men without this condition. It is not possible to examine whether or not this or other indicators of low fecundity was related to an unknown exposure of the men who declined to participate. However, since participation was rather high, the potential for selection bias was less than in most semen studies. Confounding is not likely to explain the results of this study since the main known determinants could be adequately dealt with in the statistical analysis. Moreover, we repeated the analyses of sperm concentration in relation to the long-term and short-term exposure but did not include persons with previous treatment for cryptorchidism or with less than 2 testicles in the scrotum and obtained almost the same results. The high sperm concentration compared with that of other studies may be related to season, as the sample 
was collected in winter and the sperm concentration in the northern hemisphere is highest in winter.

The number of years of work in ornamental greenhouses was related to sperm concentration, sperm velocity, and sperm vitality, but not to sperm morphology. The negative effect on spermatogenesis could have been caused by a cumulation of pesticides in testicular tissue or by previous persistent damage. In the first case organochlorides may have been involved since these compounds are likely to accumulate in the body (36). In animal testing lindane - one of the organochloride pesticides used in the greenhouses - affects the Leydig cell and diminishes testosterone release. In our study those who worked the most years in greenhouses with flower production had lower free testosterone, as indicated by the testosterone:SHBG ratio. Many factors are involved in the regulation of testosterone, and therefore no causal inference is possible, but the observation is of interest because measurable lindane levels have been reported in the human testes (37).

We found no relation between semen quality and the greenhouse-specific intensity of pesticide use. However, this measure is probably a crude index of exposure that does not integrate many other factors of importance with exposure, such as job task, location of pesticide application, and time from application to the handling of cultures. In addition, we did not find any relation between pesticide application and reduced semen quality. This result is not surprising if personal protective measures are effective because application was typically undertaken a few hours per week (mean 1.7, SD 2.3).

We consider the exposure classification based on the daily recording of job tasks, size of cultures, and amount of applied pesticide as the most reliable indicator of current dermal exposure because this measure integrates several determinants of exposure. The plasma cholinesterase activity gives some support to the interpretation that we have identified a high-level exposure group (table 2 ). The high-level exposure group had a high percentage of persons with febrile disease before the semen sample was collected (54\%), but adjustment for this factor did not change the results. Thus we do not think that residual confounding can explain the low semen quality among the men classified as having a high level of exposure. But the number of men in the high-level exposure group was small, and therefore a cautious interpretation is warranted.

Apart from the determination of plasma cholinesterase activity, we have no measurements to document the exposure classification. Nor do we know whether workers with high-level dermal exposure to pesticides are at increased risk of high-level exposure in the target tissues. The classification was mainly based on assumptions that cannot be verified within this data set. In conclusion, the results are compatible with the hypothesis that semen quality is reduced by both long-term and short-term exposure to pesticides in ornamental greenhouses. But caution is necessary in the interpretation because the exposure to pesticides was not documented by environmental or biological measurements.

\section{Acknowledgments}

The study was supported by grants from the Danish Ministry of Environment.

\section{References}

1. Garcia AM. Occupational exposure to pesticides and congenital malformations: a review of mechanisms, methods and results. Am J Ind Med 1998;33:232 - 40.

2. Kangas J, Manninen A, Liesivuori J. Occupational exposure to pesticides in Finland. Int $\mathrm{J}$ Environ Anal Chem 1995;58:423-9.

3. Nakai M, Hess RA, Netsu J, Nasu T. Deformation of the rat Sertoli cell by oral administration of carbendazim (methyl 2benximidazole carbamate). J Androl 1995;16:410 - 6 .

4. Hess RA, Moore BJ, Forrer J, Linder RE, Abuel-Atta AA. The fungicide benomyl (methyl 1-(butylcarbanoyl)-2-benzimidazolecarbamate) causes testicular dysfunction by inducing the sloughing of germ cells and occlusion of efferent ductules. Fundam Appl Toxicol 1991;17:733-45.

5. Kelce WR, Monosson E, Gamcsik MP, Laws SC, Gray LE. Environmental hormone disruptors: evidence that vinclozolin developmental toxicity is mediated by antian-drogenic metabolites. Toxicol Appl Pharmacol 1994;126:276-85.

6. Gray LE, Ostby JS, Kelce WR. Developmental effects of an environmental antiandrogen: the fungicide vinclozolin alters sex differentiation of the male rat. Toxicol Appl Pharmacol 1994;129:46-52.

7. Sinha N, Narayan R, Shanker R, Saxena D. Endosulfan-induced biochemical changes in the testis of rats. Vet Hum Toxicol 1995;37:547-9.

8. Chowdhury AR, Venkatakrishna-Bhatt H, Gautam AK. Testicular changes of rats under lindane treatment. Bull Environ Contam Toxicol 1987;38:154-6.

9. Chowdhury AR, Gautam AK. Steroidogenic impairment after lindane treatment in male rats. Sangyo Ika Daigaku Zasshi 1996;16:145-52.

10. Misha VK, Srivastava MK, Raizada RB. Testicular toxicity of thiram in rat: morphological and biochemical evaluations. Ind Health 1993;31:59-67.

11. Collins TFX. Dominant lethal assay, I: Captan. Fd Cosmet Toxicol 1972;10:363-71.

12. Jablonicka A Kobzova D. Morphological changes of sperm in experimental mice after administration of phosmet and mancozeb. Bratisl Lek Listy 1988;89:611-4.

13. Szepvölgyi J, Nagy K, Vukan KS. Subacute toxicological examination of Dithane M-45. Food Chem Toxicol $1989 ; 27: 531-8$ 
14. Pati PC, Bhunya SP. Cytogenic effects of fenvalerate in mammalian in vivo tests systems. Mutat Res 1989;222:149—54.

15. Bhunya SP, Pati PC. Effects of deltamethrin, a synthetic pyrethroid, on the induction of chromosome aberrations, micronuclei and sperm abnormalities in mice. Mutagenesis 1990;5:229-32.

16. Salem MH, Abo-Elezz Z, Abd-Allah GA, Hassan GA, Shaker N. Effect of organophosphorus (dimethoate) and pyrethroid (deltamethrin) pesticides on semen characteristics in rabbits. J Environ Sci Health B 1988;23:279-90.

17. Hemavathy $\mathrm{KC}$, Krishnamurthy NB. Evaluation of lannate 20, a carbamate pesticide in the germ cells of male mice. Environ Res 1987;42:362-5.

18. Krause W, Homola S. Alterations of the seminiferous epithelium and the leyding cells of the rat testis after the application of dichlorvos (DDVP). Bull Environ Contam Toxicol 1974;11:429-33.

19. Wyrobek AJ, Bruce WR. Chemical induction of sperm abnormalities in mice. Proc Natl Acad Sci USA 1975;72:4425-9.

20. Van Hemmen JJ, Brouwer R, Brouwer DH. Worker exposure to pesticides in greenhouses, health risks during harvesting of flowers. Med Fac Landbouww Gent 1992;57:1269—83.

21. Brouwer DH, Brouwer R, Mik DG, Maas LC, van Hemmen JJ. Pesticides in the cultivation of carnations in greenhouses: part 1 - exposure and concomitant health risk. Am Ind Hyg Assoc J 1992;53:575-81.

22. Brouwer R, Brouwer DH, Tijssen SCHA, van Hemmen JJ. Pesticides in the cultivation of carnations in greenhouses: part 2 - relationship between foliar residues and exposures. Am Ind Hyg Assoc J 1992;53:582 - 7.

23. Kangas J, Laitinen S, Jauhiainen A, Savolainen K. Exposure of sprayers and plant handlers to mevinphos in finnish greenhouses. Am Ind Hyg Assoc J 1993;54:150 - 7.

24. Archibald BA, Solomon KR, Stephenson GR. Estimating pirimicarb exposure to greenhouse workers using video imaging. Arch Environ Contam Toxicol 1994;27:126-9.

25. Frank R, Braun HE, Ritcey G, Stanek J. Pyrazophos residues from treated greenhouses and growth chamber grown chrysanthemums. Can J Plant Sci 1989;69:961—6.
26. Brouwer R, Maarleveld K, Ravensberg L, Meuling W, Kort W, van Hemmen J. Skin contamination, airborne concentrations, and urinary metabolite excretion of propoxur during harvesting of flowers in greenhouses. Am J Ind Med 1993;24:593-603.

27. Hoekstra EJ, Kiefer M, Tepper A. Monitoring of exposure to benomyl in nursery workers. Occup Environ Med 1996;38:775-81.

28. Bonde JP, Giwercman A, Ernst E, ASCLEPIOS. Identifying environmental risk to male reproductive function by occupational sperm studies: logistics and design options. Occup Environ Health 1996;53:511-9.

29. Cambridge University Press. WHO laboratory manual for the examination of human semen and sperm - cervical mucus interaction. 3rd ed. New York (NY): Cambridge University Press, 1992.

30. Kirknel E, Rasmussen AN. Pesticide re-entry exposure of workers in greenhouses: pesticide research. Copenhagen: Ministry of Environment and Energy, 1997. No 31.

31. SAS Institute Inc. SAS/STAT users guide, version 6; vol 1. 4th ed. Cary (NC): SAS Institute Inc, 1989.

32. Bonde JP. Semen quality and sex hormones among mild steel and stainless steel welders:a cross sectional study. $\mathrm{Br} \mathrm{J}$ Ind Med 1990:47:508-14.

33. Abell A, Ernst E, Bonde JP. High sperm density among members of organic farmers association. Lancet 1994;343:1498.

34. Jensen TK, Giwercman A, Carlsen E, Scheike T, Skakkebaek NE. Semen quality among members of organic food associations in Zealand, Denmark. Lancet 1996;347:1844.

35. Larsen SB, Abell A, Bonde JP. Selection bias in sperm studies. Am J Epidemiol 1998;147:681-5.

36. Smith AG. Chlorinated hydrocarbon insecticides. In: Hayes WJ, Laws ER, editors. Handbook of pesticide toxicology. San Diego (CA): Academic Press Inc, 1991.

37. Szymczynski GA, Waliszewski SM. Chlorinated pesticide residues in testicular tissue samples: pesticides in human testicles. Andrologia 1983;15:696-8.

Received for publication: 12 July 1999 